Kredo 4 (2021)
KREDO: Jurnal Ilmiah Bahasa dan Sastra
Terakreditasi Sinta 4 berdasarkan Keputusan
Direktorat Jenderal Penguatan Riset dan
Pengembangan, Kementerian Riset, Teknologi dan
Pendidikan Tinggi Republik Indonesia
Nomor: 23/E/KPT/2019.08 Agustus 2019
https://jurnal.umk.ac.id/index.php/kredo/index

\title{
ANALISIS KARAKTER TOKOH UTAMA DALAM NOVEL I AM SARAHZA KARYA HANUM SALSABIELA RAIS \& RANGGA ALMAHENDRA
}

\author{
Runi Fazalani \\ runifazalani3@gmail.com
}

Universitas Qamarul Huda Badaruddin, Indonesia

\section{Info Artikel \\ Sejarah Artikel \\ Diterima \\ 17 April 2020 \\ Disetujui \\ 15 November 2021 \\ Dipublikasikan \\ 8 April 2021}

\section{Keywords}

Character, Literary

Psychology

\section{Kata Kunci}

Karakter, Psikologi Sastra.

\section{:}

This study aims to find out about, (1) the main character's character in accordance with the workings of the heart in the novel I Am Sarahza by Hanum Salsabiela and Rangga Almahendra, (2) the main character's characters that correspond to the thought in the novel I Am Sarahza by Hanum Salsabiela and Rangga Almahendra, (3) a description of the main character in the novel I Am Sarahza by Hanum Salsabiela and Rangga Almahendra. The method used in this research is descriptive qualitative method. Research is intended to understand the phenomena about what is experienced by research subjects such as the kinds of characters possessed by the main character. By using the approach of literary psychology. The data source used by researchers is a novel entitled I Am Sarahzan by Hanum Salsabiela Rais and Rangga Almahendra. The data of this study are

: language units in the form of story unit quotations in the form of words, paragraphs, sentences that contain various characters of the main character I Am Sarahza. Data collection techniques in this research are documentary study techniques. The results of this study are, some of the characters are in accordance with the process of heart, if thought and some of the characteristics possessed by the main characters such as, (1) optimistic nature, (2) attracted to the opposite sex, (3) strong, and (4) : never give up.

\begin{abstract}
Abstrak
Penelitian ini bertujuan untuk mengetahui tentang, (1) karakter tokoh utama dengan berkesesuaian dengan olah hati dalam novel I Am Sarahza karya Hanum Salsabiela dan Rangga Almahendra, (2) karakter tokoh utama yang berkesesuaian dengan olah pikir dalam novel I Am Sarahza karya Hanum Salsabiela dan Rangga Almahendra, (3) gambaran karakter tokoh utama dalam novel I Am Sarahza karya Hanum Salsabiela dan Rangga Almahendra. Metode yang digunakan dalam penelitian ini adalah metode deskriptif kualitatif. Penelitian yang dimaksud untuk memahami fenomena-fenomena tentang apa yang dialami oleh subjek penelitian seperti macam-macam karakter yang dimiliki oleh tokoh utama. Dengan menggunakan pendekatan psikologi sastra. Sumber data yang digunakan peneliti yaitu novel yang berjudul I Am Sarahzan karya Hanum Salsabiela Rais dan Rangga Almahendra.Data penelitian ini adalah satuan-satuan bahasa yang berupa kutipan satuan cerita yang berwujud kata-kata, paragraf, kalimat yang mengandung macam-macam karakter tokoh utama I Am Sarahza.Teknik pengumpulan data dalam penelitian ini adalah berupa teknik studi dokumenter. Adapun hasil penelitian ini yaitu, beberapa karakter yang berkesesuaian dengan olah hati, olah pikir dan ada beberapa sifat yang dimiliki oleh tokoh utama seperti, (1) sifat optimis, (2) tertarik dengan lawan jenis, (3) kuat, dan (4) pantang menyerah.
\end{abstract}




Kredo 4 (2021)
KREDO: Jurnal Ilmiah Bahasa dan Sastra
Terakreditasi Sinta 4 berdasarkan Keputusan
Direktorat Jenderal Penguatan Riset dan
Pengembangan, Kementerian Riset, Teknologi dan
Pendidikan Tinggi Republik Indonesia
Nomor: 23/E/KPT/2019.08 Agustus 2019
https://jurnal.umk.ac.id/index.php/kredo/index

\section{PENDAHULUAN}

Karya sastra merupakan salah satu karya seseorang yang di dalamnya terdapat beberapa seni, jadi karya sastra merupakan sebuah gambaran atau bayangan dari seseorang atau dari suatu masyarakat. Tidak hanya sebagai bayangan karya sastra merupakan sebuah potret dalam menyangkut sebuah sosial, alam dan lain sebagainya, setelah pengendapan yang terjadi oleh seorang pengarang, maka terjadilah kehidupan yang terlahir dari pengalaman sosial yang terbentuk dalam sebuah karya sastra. Menurut Kosasih (2012: 1) sastra atau kesusastraan adalah tulisan atau karangan yang mengandung nilai-nilai kebaikan yang ditulis dalam bahasa yang indah".

Novel merupakan salah satu bentuk karya sastra yang bersifat realistis atau riell yang dimunculkan dari lingkungan di sekitar, yang berkembang dari bentukbentuk naratif nonfiksi dan secara stilistika menekankan pentingnya detail yang bersifat mimesis. Struktur novel dan segala sesuatu dikomunikasikan senantiasa dikontrol langsung oleh manipulasi bahasa pengarang. Untuk memperoleh efektivitas pengungkapan, bahasa dalam sastra disiasati, dimanipulasi dan didayagunakan secermat mungkin sehingga akan memiliki tampilan yang berbeda-beda dengan sosok yang berbeda dengan menggunakan bahasa nonsastra.
Sehingga novel isi dalam novel mampu membuat suasa hati para pembaca menjadi emosional bahkan terbawa dalam setiap isi cerita yang diimajinasikan oleh para pengarang.

Masalah yang ada dalam kehidupan selalu menjadi salah satu isi dalam sebuah cerita, dihadapi dan di alami manusia sangatlah luas dan kompleks. Setiap manusia memiliki permasalahan yang berbeda-beda, permasalahan yang ada di dalam kehidupan bersifat universal. Dalam kajian psikologi sastra, sastra membantu manusia untuk mencari kebenaran makna dalam kehidupan.

Menurut Nurgiyantoro (2015:258), tokoh utama merupakan tokoh yang diutamakan penceritaannya dalam sebuah novel yang bersangkutan. Tokoh utama selalu hadir sebagai pelaku atau yang dikenai kejadian dan konflik. Tokoh utama selalu menjadi pokok utama yang dikisahkan, sama seperti novel Sarahza, tokoh utamanya adalah Hanum, tokoh ini paling banyak hadir di saat awal cerita sampai akhir cerita. Tokoh utama dalam novel ini sering mengalami perubahan karakter karena setiap karakter seseorang dapat berubah karena karakter seseorang dapat dipengaruhi oleh lingkungan sekitar atau keadaan yang dialami oleh tokoh tersebut. Karakter sangat berbeda sekali dengan watak. Watak tidak dapat berubah sedangkan karakter dapat berubah seiring perkembangan waktu dan keadaan sang tokoh. Karakter tokoh 


Kredo 4 (2021)
KREDO: Jurnal Ilmiah Bahasa dan Sastra
Terakreditasi Sinta 4 berdasarkan Keputusan
Direktorat Jenderal Penguatan Riset dan
Pengembangan, Kementerian Riset, Teknologi dan
Pendidikan Tinggi Republik Indonesia
Nomor: 23/E/KPT/2019.08 Agustus 2019
https://jurnal.umk.ac.id/index.php/kredo/index

utama dapat dilihat melalui ekspresi diri dalam bentuk tingkah laku dalam cerita (Sujanto, 2004: 19).

Karakter merupakan salah satu bagian dari sebuah karya sastra paling dalam dan paling penting, terutama dalam sebuah novel, karakter di ciptakan oleh seorang pengarang untuk menyampaikan sebuah gagasan dan perasaan seseorang yang terjadi di dunia ini melalui seorang tokoh dalam sebuah karya sastra, misalnya pada novel, cerpen dan lain sebagainya. sebuah karakter memiliki kekuatan tersendiri dalam sebuah cerita secara keseluruhan di dalam sebuah karya sastra. Seorang pengarang mampu membawa karakter tersebut melalui suatu permasalahan dalam situasi yang berbeda-beda. Menurut Grolier (1977: 291), karakterisasi merupakan ciri-ciri unik dari bentuk fiksi seperti cerita pendek, novel, drama, dan puisi narasi.

Ketika seorang pembaca membaca sebuah karya sastra misalnya novel, maka akan timbul sebuah perasaan dan melihat cerita tentang kehidupan dari masing-masing karakter dalam novel. Seorang pengarang menulis sebuah novel bukan untuk menimbulkan perasaan senang kepada pembaca akan tetapi menyampaikan sebuah pesan tentang kejadian dan aksi para tokoh dalam novel itu. Pengarang mendeskripsikan bahwa setiap orang memiliki perbedaan dalam karakter, seperti tempramental, perasaan

\section{5 | Jurnal Kredo}

Vol. 4 No. 22021 memiliki, dikucilkan, pantang menyerah, kuat atau rasa humor.

I Am Sarahza adalah sebuah novel karya Hanum Salsabiela Rais dan Rangga Almahendra yang diterbitkan oleh Republika Penerbit pada tahun 2018. Novel I Am Sarahza menceritakan tentang Hanum dan Suaminya yang mengalami pergolakan, tidak hanya fisiknya saja tetapi juga batinnya. Hal tersebut dikarenakan Hanum dan suaminya yang ingin segera mempunyai anak sehingga membuat ia merasa sedih, terpuruk, hingga ia mendapatakan kekuatannya yang luar biasa untuk terus mencoba dan mengikuti prosedur program hamil berkali-kali.

Alasan peneliti memilih novel I Am Sarahza sebagai kajian penelitian ini adalah novel I Am Sarahza merupakan novel yang tergolong baru dan belum pernah di analisis karakter tokoh utamanya. Selain itu novel I Am Sarahza memiliki jalan cerita yang mampu memberi motivasi dan inspirasi untuk semua orangtua yang selalu gagal dalam berjuang dan selalu bersabar untuk mendapatkan keturunan.

Penelitian pada I Am Sarahza membahas tentang karakter seorang tokoh utama. Adapun alasan peneliti menganalisis karakter tokoh utama karena, peneliti mendapat beberapa karakter yang di lakoni oleh tokoh utama dalam novel I Am Sarahza seperti, penyabar, pekerja keras, pantang menyerah, kuat, dan lemah. 


Kredo 4 (2021)
KREDO: Jurnal Ilmiah Bahasa dan Sastra
Terakreditasi Sinta 4 berdasarkan Keputusan
Direktorat Jenderal Penguatan Riset dan
Pengembangan, Kementerian Riset, Teknologi dan
Pendidikan Tinggi Republik Indonesia
Nomor: 23/E/KPT/2019.08 Agustus 2019
https://jurnal.umk.ac.id/index.php/kredo/index

Penelitian menganalisis karakter yang dialami tokoh utama pada novel I Am Sarahza. Alasan peneliti menganalisis tokoh utama karena; pertama, tokoh utama selalu hadir sebagai pelaku yang selalu di utamakan karakternya yang sangat memengaruhi perkembangan plot atau alur dalam novel I Am Sarahza. Kedua, semua tokoh saling berhubungan dalam sebuah peristiwa atau kejadian dalam sebuah karakter.

Fokus penelitian ini yaitu mengenai macam-macam karakter individu tokoh utama yaitu: olah hati dan olah pikir, Oleh karena itu dengan menetapkan fokus penelitian ini bertujuan agar penelitian yang dilakukan lebih terarah dan tidak keluar dari bentuk karakter yang diteliti. Ruang lingkup penelitian ini mencakup hubungan karya sastra yang diteliti serta cakupan kejadian berdasarkan karakter individu yang telah diungkapkan oleh (Samani dan Hariyanto, 2011:25), yang meliputi (1) olah hati, (2) olah pikir, (3) olah raga, dan (4) olah rasa dan karsa. Keempat bentuk ini merupakan salah satu cara untuk menemukan karakter yang dibutuhkan oleh seiap individu.

Penelitian tentang macam-macam karakter individu tokoh utama yaitu olah hati dan olah pikir dalam novel I Am Sarahza karya Hanum Salsabiela Rais dan Rangga Almahendra sampai saat ini belum pernah dilakukan oleh peneliti sebelumnya. Berdasarkan penelusuran yang peneliti lakukan, terdapat penelitian yang relevan dengan peneliti sebelumnya sebagai berikut.

Peneliti sebelumnya Izza Putri Rizki tahun 2019 dengan judul "Dimensi Keagamaan dalam Novel I Am Sarahza Karya Hanum Salsabiela Rais dan Rangga Almahendra: Kajian Semiotika dan Implementasi Sebagai Bahan Ajar di SMA" Progam Studi Pendidikan Bahasa dan Sastra Indonesia, Fakultas Keguruan dan Ilmu Pendidikan, Universitas Muhammadiyah Surakarta. Hasil penelitiannya diuraikan sebagai berikut. Pertama, mendeskripsikan struktur yang membangun novel I Am Sarahza karya Hanum Salsabiela Rais dan Rangga Almahendra. Kedua, mendeskripsikan dimensi keagamaan yang terkandung dalam novel I Am Sarahza karya Hanum Salsabiela Rais dan Rangga Alamhendra. Ketiga mendeskripsikan implementasi nilai keagamaan novel I Am Sarahza karya Hanum Salsabiela Rais dan Rangga Almahendra sebagai bahan ajar di SMA. Sedangkan peneliti meneliti tentang macam-macam karakter individu tokoh utama yaitu olah hati dan olah pikir dalam novel I Am Sarahza karya Hanum Salsabiela Rais dan Rangga Almahendra.

Selanjutnya Yuniarti, Antonius Totok Priyadi, Sesilia Seli, (2019) dengan judul "Analisis Konflik Tokoh dalam Novel I Am Sahraza Karya Hanum Salsabiela Rais dan Rangga Almahendra". Adapun hasil 


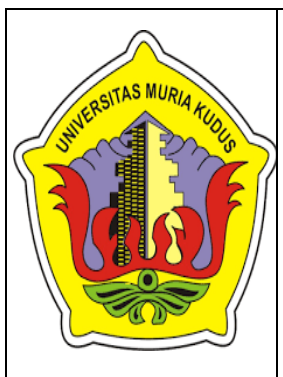
Kredo 4 (2021)
KREDO: Jurnal Ilmiah Bahasa dan Sastra
Terakreditasi Sinta 4 berdasarkan Keputusan
Direktorat Jenderal Penguatan Riset dan
Pengembangan, Kementerian Riset, Teknologi dan
Pendidikan Tinggi Republik Indonesia
Nomor: 23/E/KPT/2019. 08 Agustus 2019
https://jurnal.umk.ac.id/index.php/kredo/index

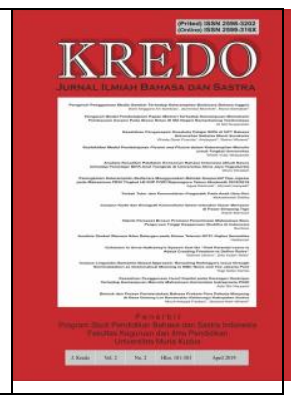

penelitiannya yaitu: (1) Konflik Internal Tokoh dalam Novel Iam Sarahza karya Hanum Salsabiela Rais dan Rangga Alamhendra, seperti perasaan gelisah, takut, sedih, kecewa, terharu, dan marah, (2) Konflik Eksternal Tokoh dalam Novel Iam Sarahza karya Hanum Salsabiela Rais dan Rangga Alamendra. Seperti: Konflik antara Hanum dan Farida, Konflik antara Hanum dan Rangga, Konflik antara Hanum dan Tuhannya, Konflik antara Hanum dan Dirinya Sendiri, dan (3) Rencana Implementasi yang dihasilkan Berdasarkan Penelitian pada Novel I Am Sarahza Karya Hanum Salsabiela Rais dan Rangga Almahendra. Sebagai Bahan Pembelajaran Teks Narasi. Sedangkan peneliti hanya meneliti tentang karakter individu tokoh utama yaitu olah hati dan olah pikir dalam novel I Am Sarahza karya Hanum Salsabiela Rais dan Rangga Almahendra.

Berdasarkan uraian pendahuluan di atas maka peneliti menarik rumusan masalahnya sebagai berikut:

Bagaimana karakter tokoh utama yang berkesesuaian dengan olah hati dalam novel I Am Sarahza karya Hanum Salsabiela dan Rangga Almahendra?, (2) bagaimana karakter tokoh utama yang berkesesuaian dengan olah pikir dalam novel I Am Sarahza karya Hanum Salsabiela dan Rangga Almahendra?, (3) bagaimanakah gambaran karakter tokoh utama dalam novel I Am Sarahza karya
Hanum Salsabiela dan Rangga Almahendra?

\section{KAJIAN TEORI}

Suryabrata (2002: 10-13) memaparkan, tipologi kepribadian menurut Hippocrates (460-377 SM) dan Galenus (129-200 M) dipengaruhi oleh kosmologi Empedokles, yang menganggap bahwa alam beserta isinya tersusun dari empat unsur dasar yaitu: air, tanah, udara, dan api; dengan sifatsifat yang didukungnya yaitu: kering, basah, panas dan dingin. Berdasarkan empat unsur tersebut berserta sifat pendukungnya, maka Hippocrates berpendapat bahwa, dalam diri seseorang terdapat empat macam sifat tersebut yang didukung oleh keadaan konstitusional yang berupa cairan-cairan yang ada dalam tubuh seseorang, yaitu: (a) sifat kering terdapat dalam chole (empedu kuning), (b) sifat basah terdapat dalam melanchole (empedu hitam), (c) sifat dingin terdapat dalam phlegma (lendir), dan (d) sifat panas terdapat dalam I (darah). Keempat cairan tersebut ada dalam tubuh dalam proporsi tertentu. Apabila semua cairan-cairan di dalam tubuh seseorang tersebut berada dalam proporsi selaras (normal), maka orang tersebut dikatakan normal atau sehat. Namun apabila keselarasan proporsi tersebut terganggu maka orang tersebut menyimpang dari keadaan normal atau sakit. 


Kredo 4 (2021)
KREDO: Jurnal Ilmiah Bahasa dan Sastra
Terakreditasi Sinta 4 berdasarkan Keputusan
Direktorat Jenderal Penguatan Riset dan
Pengembangan, Kementerian Riset, Teknologi dan
Pendidikan Tinggi Republik Indonesia
Nomor: 23/E/KPT/2019.08 Agustus 2019
https://jurnal.umk.ac.id/index.php/kredo/index

Karakter seorang tokoh dalam sebuah karya fiksi sering disebut dengan penokohan atau perwatakan. Menurut Kosasih (2012: 67), karakter tokoh merupakan cara seorang pengarang untuk menggambarkan dan mengembangkan karakter tokoh-tokoh dalam cerita. Sedangkan menurut Zaidan (2004: 206), kerakter tokoh merupakan sebuah proses penampilan tokoh dengan pemberian sifat, watak, atau kebiasaan tokoh pemeran suatu cerita. Perwatakan atau karakter tokoh adalah pemberian sifat baik lahir maupun batin pada seorang pelaku atau tokoh yang terdapat pada cerita Sugiarti (2007: 94). Berdasarkan uraian di atas maka karakter tokoh merupakan salah satu gambaran yang dipaparkan oleh seorang pengarang dan disimpulkan dalam sebuah karya sastra.

Di dalam sebuah karya fiksi, nilai karakter merupakan sebuah unsur intrinsik. Unsur intrinsik merupakan unsur-unsur yang membangun karya sastra itu sendiri. Unsur-unsur inilah yang menyebabkan karya sastra hadir sebagai karya sastra, unsur-unsur yang secara faktual akan dijumpai jika orang membaca karya sastra. Nurgiyantoro (2007) menjelaskan bahwa unsur intrinsik sebuah novel adalah unsurunsur yang secara langsung turut serta membangun cerita. Kepaduan antarberbagai unsur intrinsik inilah yang membuat sebuah novel terwujud. Jika dilihat dari sudut pandang pembaca, unsur-unsur cerita yang dijumpai ketika membaca sebuah novel, yaitu peristiwa, cerita, plot, penokohan, tema, latar, sudut pandang penceritaan, bahasa atau gaya bahasa, dan lain-lain.

\section{METODE PENELITIAN}

Metode penelitian adalah cara yang digunakan peneliti untuk memecahkan masalah dalam penelitian yang dilakukannya. Berdasarkan tujuan penelitian ini, metode yang digunakan dalam penelitian ini adalah metode deskriptif. Menurut Nawawi (2012: 67) metode deskriptif dapat diartikan sebagai prosedur pemecahan masalah yang diselidiki dengan menggambarkan atau melukiskan keadaan subjek atau objek penelitian pada saat sekarang berdasarkan fakta-fakta yang tampak, atau sebagaimana adanya.

Adapun bentuk penelitian yang digunakan adalah penelitian kualitatif, yaitu penelitian yang dimaksud untuk memahami fenomena-fenomena tentang apa yang dialami oleh subjek penelitian seperti macam-macam karakter yang dimiliki oleh tokoh utama, Menurut Maleong (2006: 11-12) menyatakan penelitian kualitatif lebih banyak mementingkan proses dari pada hasil. Hal ini disebabkan oleh hubungan bagian-bagian yang sedang diteliti akan jauh lebih jelas apabila diamati dalam proses. 


Kredo 4 (2021)
KREDO: Jurnal Ilmiah Bahasa dan Sastra
Terakreditasi Sinta 4 berdasarkan Keputusan
Direktorat Jenderal Penguatan Riset dan
Pengembangan, Kementerian Riset, Teknologi dan
Pendidikan Tinggi Republik Indonesia
Nomor: 23/E/KPT/2019.08 Agustus 2019
https://jurnal.umk.ac.id/index.php/kredo/index

Pendekatan yang digunakan dalam penelitian ini adalah pendekatan psikologi sastra sebagai salah satu cara analisis berdasarkan sudut pandang psikologi, sudut pandang yang bertolak belakang dari asumsi bahwa karya sastra selalu membahas tentang peristiwa kehidupan manusia yang merupakan pancaran heart menghayati dan menyikapi kehidupan.

Adapun sumber data yang digunakan peneliti yaitu novel yang berjudul I Am Sarahzan karya Hanum Salsabiela Rais dan Rangga Almahendra. Novel ini terdiri dari 368 halaman, yang di terbitkan oleh Republika Penerbit, Jakarta di terbitkan pada tahun 2018. Data penelitian ini adalah satuan-satuan bahasa yang berupa kutipan satuan cerita yang berwujud kata-kata, paragraf, kalimat yang mengandung macammacam karakter tokoh utama I Am Sarahza, Kemudian data dideskripsikan dan dianalisis menggunakan teori yang telah dipaparkan dalam landasan teori.

Teknik pengumpulan data dalam penelitian ini adalah berupa teknik studi dokumenter. Menurut Sugiyono (2008: 82) teknik dokumentasi merupakan tekni yang mengumpulkan data berupa tulisan, gambar, atau karya-karya monumental dari seseorang. Teknik dokumentasi yang digunakan oleh peneliti berguna untuk mengambil data dalam bentuk tulisan yang memberikan informasi bagi peneliti. Teknik studi dokumenter dilakukan dengan cara 449 | Jurnal Kredo Vol. 4 No. 22021 menelaah karya sastra yang menjadi sumber data dalam penelitian. Oleh karena itu, penulis menggunakan novel I Am Sarahza karya Hanum Salsabiela Rais dan Rangga Almahendra sebagai sumber data. Teknik pengumpulan data dilakukan dengan cara sebagai berikut. (a), membaca secara cermat novel I Am Sarahza karya Hanum Salsabiela Rais dan Rangga Almahendra (b), mengidentifikasi macam-macam karakter internal dan eksternal yang terkandung dalam novel I Am Sarahza karya Hanum Salsabiela Rais dan Rangga Almahendra (c), Mengelompokkan karakter yang telah diperoleh (d), menguji keabsahan data menggunakan ketekunan pengamatan, teknik triangulasi antarpeneliti dan kecukupan referensi.

\section{HASIL DAN PEMBAHASAN}

\section{KARAKTER TOKOH UTAMA YANG BERKESESUAIAN DENGAN OLAH HATI}

Olah hati merupakan suatu kemampuan seseorang untuk mengelola hati nurani sehingga dapat memutuskan kebenaran dan kesalahan atau perbuatanperbuatan secara individual diri sendiri. Seperti kutipan pertama dalam novel I Am Sarahza karya Hanum Salsabiela Rais dan Rangga Almahendra,

$$
\begin{aligned}
& \text { "Buatku nggak punya anak } \\
& \text { juga nggak papa”, hanum } \\
& \text { menelan ludah.Alisku }
\end{aligned}
$$




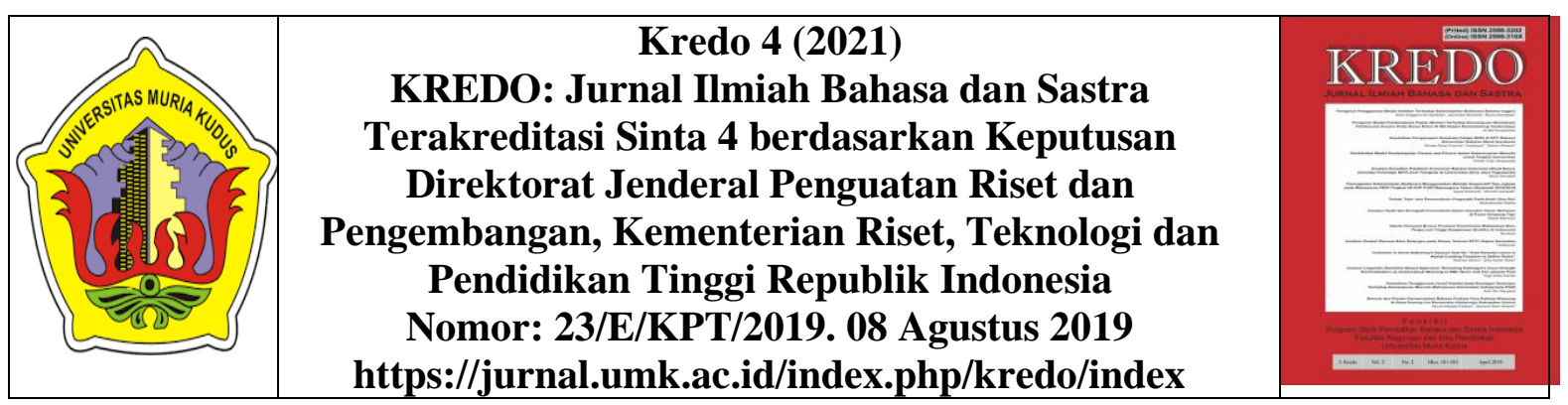

berkerut. Kalimat Hanunm terdengar mantap. Yang kuhawatirkan sekarang ini, bukan diriku lagi jika harus sendiri menjalani hari-hari di Wina alias LDR-an dengannya. Tapi .... Jika kalimat Hanum diamini malaikat di sekitarnya". (Hanum Salsabiela Rais dan Rangga Almahendra: 53)

Kutipan di atas menjelaskan bahwa tokoh utama memiliki karakter selalu percaya diri dengan apa yang dia inginkan dan kokoh dalam pendiriannya, meskipun dia telah mengatakan suatu kesalahan dalam ucapannya, kesalahan yang mengakibatkannya dia harus rela berpisah dengan suaminya yang akan melanjutkan kuliahnya di luar negri. Pembentukan karakter yang baik dalam diri remaja menurut Samani dan Hariyanto (2011: 24), menyatakan bahwa diperlukan individu-individu yang berkarakter khusus. Secara psikologis, karakter individu dimaknai sebagai hasil keterpaduan empat bagian yakni olah hati, olah pikir, olah raga, olah rasa dan karsa. keempat hal ini diperlukan untuk mengarahkan suatu pembangunan karakter yang baik.

Adapun kutipan selanjutnya yang terdapat dalam novel I Am Sarahza adalah sebagai berikut,

$\begin{array}{lr}\text { "Berat awalnya menaati } \\ \text { keputusan } & \text { demi } \\ \text { mengikuti } & \text { kata-kata }\end{array}$

orangtua untuk mendampingi Rangga ke Austria. Meletakkan apa yang telah aku capai, meninggalkan segala eksistensi yang telah aku upayakan, bahkan memnsiunkan dini dokter gigi. Setidaknya di sini di Wina aku memiliki segepok harapan baru. Hidup di luar negri, playing tourist, belajar bahasa jerman, meneruskan sekolah yang tertunda karena karier, magang di sebuah perusahaan media luar, jadi koresponden TV Indonesia, hingga aku sudah punya back up plan”. (Hanum Salsabiela Rais dan Rangga Almahendra: 65)

Berdasarkan kutipan di atas karakter tokoh utama tidak hanya keras akan tetapi penurut dan lembut, meskipun awalnya dia tidak menginginkan ikut bersama suaminya akan tetapi dengan perintah orangtua dia rela meninggalkan kariernya demi suaminya ke luar negeri, dan rela berjuang untuk mempertahankan kariernya di sana, karakter tokoh utama sangat jelas dipaparkan bahwa karakter 


Kredo 4 (2021)
KREDO: Jurnal Ilmiah Bahasa dan Sastra
Terakreditasi Sinta 4 berdasarkan Keputusan
Direktorat Jenderal Penguatan Riset dan
Pengembangan, Kementerian Riset, Teknologi dan
Pendidikan Tinggi Republik Indonesia
Nomor: 23/E/KPT/2019.08 Agustus 2019
https://jurnal.umk.ac.id/index.php/kredo/index

tokoh utama berkesesuaian dengan olah hati atau etika seorang tokoh sangat baik, seperti yang telah di paparkan oleh Malawi (2010: 3) karakteristik yang berkualitas perlu di bentuk dan dibina sejak anak memasuki usia dini merupakan masa kritis untuk pembentukan karakter seseorang. Sesuai dengan yang ditanamkan oleh orangtua seorang tokoh utama kepada anaknya yang menuruti semua perkataannya.

Kutipan selanjutnya yang terdapat dalam novel yaitu.

Rasanya perjalanan yang kutempuh tak hanya jauh, tapi mendaki berliku tanpa tahu ujungnya. Kami buta tentang scenario film, apalagi membuat film. Akhirnya, semua tetek bengek adaptasi novel ke film kuserahkan pada produser dan sutradara yang ditubjuk (Hanum Salsabiela Rais dan Rangga Almahendr: 169)

Kutipan di atas menunjukkan bahwa rasa yang dialami oleh penulis novel 99 Cahaya atau tokoh utama dalam novel ini sangat tidak percaya diri dengan apa yang akan dia lakukan dalam membuat sebuah film, membuat hatinya tidak tenang setiap malam, bahkan tokoh utama tidak percaya dengan kemampuan yang dia miliki, sehingga menyerahkan semuanya kepada sutradara yang akan memfilmkan novelnya. Jadi karaklter tokoh utama di dalam novel ini di gambarkan kalau dia tidak percaya diri dengan apa yang akan dia lakukan bahkan sering was-was karena belum pernah mencobanya.

\section{KARAKTER TOKOH UTAMA YANG BERKESESUAIAN DENGAN OLAH PIKIR}

Olah pikir merupakan Kemampuan seseorang untuk mengelola akal budi untuk mempertimbangkan dan memutuskan sesuatu baik dalam memecahkan suatu permasalahan yang sedang dihadapi. Sangat jelas dipaparkan di dalam novel I Am Sarahza karya Hanum Salsabiela Rais dan Rangga Almahendra. Karakter tokoh utama yang berkesesuaian dengan olah pikir sangat jelas di gambarkan dalam sebuah kutipan di bawah ini,

"Tiga tahun menikah, Ayah
dan Ib memutuskan ikut
program hamil lewat
inseminasi. Sebagai
penyandang gelar sarjana
teknik, Ayah percaya
banyak permasalahan di
dunia diatasi dengan
rekayasar mekanik".
(Hanum Salsabiela Rais
dan Rangga Almahendra:
72)

Berdasarkan kutipan di atas karakter tokoh utama yang berkesesuaian dengan olah pikir, tokoh utama yang berani mengambil sebuah keputusan meskipun itu sulit untuk dilakukan 


Kredo 4 (2021)
KREDO: Jurnal Ilmiah Bahasa dan Sastra
Terakreditasi Sinta 4 berdasarkan Keputusan
Direktorat Jenderal Penguatan Riset dan
Pengembangan, Kementerian Riset, Teknologi dan
Pendidikan Tinggi Republik Indonesia
Nomor: 23/E/KPT/2019.08 Agustus 2019
https://jurnal.umk.ac.id/index.php/kredo/index

karena keinginan yang kuat untuk memiliki seorang anak, sehingga rela melakukan program kehamilan di luar negeri dengan mengeluarkan biaya yang tidak sedikit, dengan begitu tokoh utama ingin memecahkan masalahnya dengan suatu usaha. Menurut Foester (dalam Adisusilo, 2011: 77), karakter merupakan suatu yang mengualifikasi seorang pribadi. Karakter menjadi identitas, menjadi ciri, menjadi sifat yang tetap, atau bisa dikatakan karakter merupakan seperangkat nilai yang telah menjadi kebiasaan hidup sehingga menjadi sifat tetap dalam diri seseorang.

Kutipan selanjutnya dalam novel I Am Sarahza yang membahas tentang olah pikir atau kemampuan seseorang dalam memutuskan sesuatu yang baik di gambarkan oleh tokoh seperti kutipan di bawah ini,

"Mas, kita batalin mendekat hajar Aswad yah, Aku juga ngak pingin jubel-jubelan di Multazam.Kita sudah pernah lakuin itu pas haji dulu. Sudah cukup. Kita duduk menjauh saja dari kerumunan, sambil menatap ka'bah. Biar berdoanya bisa khusyuk nggak tergesa-gesa". (Hanum Salsabiela Rais dan Rangga Almahendra: 296)
Kutipan di atas menjelaskan bahwa tokoh utama sangat mengikhlaskan dirinya untuk berjauhan dengan ka'bah supaya doanya lebih khusuk meskipun target awalnya bersimpu di hadapan ka'bah, akan tetapi dengan kebesaran hati tokoh utama mereka dan mengikhlaskannya dan memutuskan untuk tidak di dekata ka'bah.

Kutipan selanjutnya adalah bagaimana orangtua rela dan ikhlas untuk mengambil keputusan buat anak perempuannya supaya dia mendapatkan keturunan,

"Pasangan suami istri itu bergandengan tangan setelah turun dari sebuah mobil di anjungan sebuah rumah sakit. Mereka menoleh ke kanan dank $e$ kiri, celingak-celinguk seperti kehilangan arah.Baik si istri dan suami tak lagi muda.Seorang pegawai rumah sakit berjalan melewati mereka berdua.

"Maaf Mba. Poloklinik Infertilitas ada di sebelah mana ya dari rumah sakit Kami mau mendaftar." (Hanum Salsabiela Rais dan Rangga Almahendra: 301)

Berdasarkan kutipan di atas orangtua yang memiliki karakter baik dan luhur selalu memperhatikan anaknya 


Kredo 4 (2021)
KREDO: Jurnal Ilmiah Bahasa dan Sastra
Terakreditasi Sinta 4 berdasarkan Keputusan
Direktorat Jenderal Penguatan Riset dan
Pengembangan, Kementerian Riset, Teknologi dan
Pendidikan Tinggi Republik Indonesia
Nomor: 23/E/KPT/2019.08 Agustus 2019
https://jurnal.umk.ac.id/index.php/kredo/index

meskipun dengan penuh pertimbangan untuk pergi ke rumah sakit untuk membuat anaknya bahagia dan memiliki keturunan, meskipun kecil kemungkinan akan tetapi dengan keyakinan yang kuat orangtua rela melakukan apapun demi anak-anaknya. Karakter orangtua itu sungguh bijaksana meskipun semua orang memandangnya dengan sebelah mata, tapi dengan kegigihannya orangtua itu merupakan ujung tombak buat anakanaknya. Menurut Thomas Lickona (2012: 81) seseorang perlu untuk mengendalikan diri sendiri misalnya, dari segi keinginan, hasrat, untuk melakukan hal yang baik untuk orang lain. Sama halnya dengan orangtua tokoh utama yang rela melakukan apapun untuk anakanaknya, meskipun sakit tidak akan pernah dia rasakan.

Dalam hal ini karakter tokoh utama selalu berfikir negatif kepada seseorang yang belum pernah dia kenal seperti kutipan di bawah ini.

"Gini aja deh Mas. Kasihin aja itu demonyake pak satpam Taryo yang jaga parkiran. Nanti saya samperin habis saya ngerjain pasien." "Oh gitu.." jawab si Mas Hasan. Nadanya kecewa. Sorry Mas. Pasienku jauh lebih berharga dari demo lagumu yang... sudah pasti jelek. Lagian, mau latihan band? Apa urusanku?, gumam hatiku jahat. "ngak bisa turun sebentar ya Mbak? Balasannya sedikit memaksa."

(Hanum Salsabiela Rais dan Rangga

Almahendra:14-15)

Kutipan di atas menjelaskan bahwa karakter tokoh utama sangat judes dan keras kepala meskipun dia seringkali meremehkan janji dengan orang lain, karena tokoh utama selalu mengganggap dirinya paling benar sehingga merugikan orang lain baik dari segi waktu tenaga dan lain sebagainya.

GAMBARAN KARAKTER TOKOH UTAMA DALAM NOVEL I AM SARAHZA

Berdasarkan gambaran karakter tokoh utama pada novel I Am Sarahza karya Hanum Salsabiela Rais dan Rangga Almahendra terdapat beberapa karakter yang dilakoni oleh tokoh utama seperti yang di gambarkan dalam sifat internal tokoh. Lauther (2004: 3) mengungkapkan bahwa sifat internal dapat diperoleh dari waktu ke waktu tergantung pada pengalaman karakter, misalnya pendidikan dan lingkungan sosial, atau insiden spesifik yang telah terjadi dalam hidupnya. Sebuah sifat atau karakter adalah hasil dari apa yang dilihat, di dengar atau dialami.

\section{Optimis}

Sifat yang dimiliki oleh tokoh utama I Am Sarahza cendrung menonjolkan sifat optimis di saat di 


Kredo 4 (2021)
KREDO: Jurnal Ilmiah Bahasa dan Sastra
Terakreditasi Sinta 4 berdasarkan Keputusan
Direktorat Jenderal Penguatan Riset dan
Pengembangan, Kementerian Riset, Teknologi dan
Pendidikan Tinggi Republik Indonesia
Nomor: 23/E/KPT/2019.08 Agustus 2019
https://jurnal.umk.ac.id/index.php/kredo/index

hadapi suatu masalah ataupun di saat mengambil keputusan sama seperti kutipan di bawah ini,

"Aku lekas-lekas
mengangguk.
"Bisa banget Mas.Besok
ya, mas Hassan. Kalau
luang waktunya, bisa
datang ke lantai 4 jam 8
pagi. Makasih banget!"
Pria itu mengepalkan
jempol. Ia tidak pernah
tahu mengapa aku sangat
berterima kasih padanya.
Aku semakin semangat
mengirimkan SMS ke
Arto setelah ini. Mas
Arto, silahkan Mas Arto
jualan gigi ke yang lain,
sayar udahr dapat
gratisan.
"Oya satu lagi Mba
Hanum."
"Ya?"
"Nanti kalau nulis nama
di rekaman medic
pendaftaran, nama saya
rangga Almahendra ya,
bukan Hassan." (Hanum
Salsabiela Rais dan
Rangga Alamahendra:
31)

Dengan sifat yang optimis hanum yakin dengan apa yang akan dia lakukan dan yakin dengan semua yang dia kerjakan meskipun orang memerasnya tapi dia yakin Allah maha adil dan kuasa atas segalanya, dengan pertolongan Rangga, Hanum menjadi lebih bahagia.

\section{Tertarik dengan Lawan Jenis}

Setiap manusia memiliki hasrat untuk saling memiliki sama halnya dengan Hanum dan Rangga yang samasama jatuh cinta ketika kekalahan melanda di saat pemilihan presiden. Seperti kutipan di bawah ini,

"Tak terawsa, indra pengelihatanku memburam oleh genangan air mata. Rangga menatapku dan refleksnya menyeka air mataku dengan sehelai tisu. Setelah lima tahun, aku baru tahu apa makna wejangan bapak, Aku harus mencintai di mana aku berada sekarang, karena di akhiran ada berkah yang menjemputku. Berkah itu barangkali manusia yang sekarang berhadaphadapan denganku. Tatapan dan sentuhannya di pelupuk mata barusan, menjadi sebuah titik balik keputusan."(Hanum

Salsabiela Rais dan Rangga Almahendra: 46-47)

Berdasarkan kutipan di atas hanum memiliki rasa kepada rangga dan rangga juga sebaliknya, rasa itu muncul dari 


Kredo 4 (2021)
KREDO: Jurnal Ilmiah Bahasa dan Sastra
Terakreditasi Sinta 4 berdasarkan Keputusan
Direktorat Jenderal Penguatan Riset dan
Pengembangan, Kementerian Riset, Teknologi dan
Pendidikan Tinggi Republik Indonesia
Nomor: 23/E/KPT/2019.08 Agustus 2019
https://jurnal.umk.ac.id/index.php/kredo/index

hati yang saling memiliki rasa ingin memiliki, hanum adalah seorang dokter gigi dan anak dari seorang calon presiden, memiliki sifat tertarik kepada sesama manusia.

Kutipan selanjutnya adalah sebagai berikut.

"Terus terang aku tidak
pernah bertemu dengan
pemuda yang cukup sopan
dan tidak mony oriented
seperti Rangga. Ia tidak
seperti orang-orang yang
merubungku dan tanpa ba-
bi-bu menjelajali dengan
proposal pembiayaan
kampanye."
(Hanum Salsabiela Rais dan
Rangga Almahendra: 32)

Kutipan di atas menjelaskan karakter tokoh utama yang memiliki ketertarikan kepada lawan jenis yang baru dia kenal, dan menggambarkan kriteria laki-laki yang dia suka. Laki-laki yang baik sopan mampu meluluhkan hatinya.

\section{Kuat}

Berdasarkan gambaran di dalam novel I Am Sarahza seorang tokoh wanita yang memiliki kekuatan dalam sebuah keyakinan meskipun gagal seribu kali dalam mencoba untuk program anak, meskipun dia takut dengan segala yang berhubungan dengan rumah sakit apalagi jarum suntik, seperti kutipan di bawah ini,

\section{5 | Jurnal Kredo}

Vol. 4 No. 22021
"Jadi nanti saya akan di suntik ya Dok?" tanya Hanum serak.

"Sangat. Dan untuk mengecek semua hormone sudah dalam kadar tertentuyang diharapkan, pengambilan darah rutin akan dilaksanakan." Wajah Hanum mengerut lebih dalam, menelan ludah. Aku tahu ia begitu takut dengan jarum suntik sejak kuliah dulu."

(Hanum Salsabiel Rais dan Rangga Almahendra: 93)

Berdasarkan gambaran di atas, Hanum begitu takut dengan jarum suntik akan tetapi demi mendapatkan keturunan dia rela melakukan apapun untuk mendapatkannya dan melakukannya dan selalu merasa kuat meskipun dia harus berhadapan dengan jarum suntik setiap hari.

Perhatikan kutipan selanjutnya di bawah ini.

"Hai jarum suntik. Aku sangat membencimu. Dari sejak aku kuliah dulu. But you know what? Jika untuk memperoleh Sarahza aku harus bertemu denganmu ribuan kali, aku sanggup. Sanggup untuk 'mencintaimu' setulustulusnya," sapa Hanum 


Kredo 4 (2021)
KREDO: Jurnal Ilmiah Bahasa dan Sastra
Terakreditasi Sinta 4 berdasarkan Keputusan
Direktorat Jenderal Penguatan Riset dan
Pengembangan, Kementerian Riset, Teknologi dan
Pendidikan Tinggi Republik Indonesia
Nomor: 23/E/KPT/2019. 08 Agustus 2019
https://jurnal.umk.ac.id/index.php/kredo/index

pada jarum suntik." (Hanum Salsabiel Rais dan Rangga Almahendra:353)

Berdasarkan kutipan di atas karakter tokoh utama dapat digambarkan bahwa tokoh utama memiliki jiwa yang kuat untuk mendapatkan sesuatu. Tokoh utama berani melawan rasa takut yang selama ini bersemayam dalam dirinya hanya untuk mendapatkan seorang anak.

Kutipan selanjutnya tentang karakter tokoh utama adalah sebagai berikut.

"Wajah Hanum mengerut dalam, menelan ludah. Aku tahu ia begitu takut dengan jarum suntik sejak kuliah dulu, ia mengidap Trypanophobia ringan, jika melihat jarum suntik. Penyakit satu ini memang aneh, jika melihat jarum suntik Hanum langsung memucat dan berdebardebar. Tidak sampai menjerit-jerit atau pingsan, tapi perasaan tak nyaman ketika melihat atau membayangkan jarus suntik menembus kulit lumayan menaikkan tensinya."

(Hanum Salsabiel Rais dan Rangga Almahendra:93)
Kutipan di atas menjelaskan bahwa karakter tokoh utama memiliki penyakit Trypanophobia, penyakit ini sama hal nya dengan trauma yang tidak bisa hilang yang mampu membuuat sesorang menjadi takut setakut-takutnya sehingga rasa itu selalu menyelimuti pikirannya. Tokoh utama takut sekali dengan jarum suntik, akan tetapi dia tidak memiliki pilihan lain selain itu untuk mendapatkan keturunan dia harus melakukannya.

\section{Pantang Menyerah}

Karakter tokoh utama dalam novel I Am Sarahza tidak hanya kuat akan tetapi dengan sifatnya yang pantang menyerah membuat dia mendapatkan apa yang iya impikan selama ini, dengan usahanya sampai berkali-kali pada akhirnya dia memiliki keturunan, seperti kutipan di bawah ini,

"Buk, hari ini juga aku dan mas Rangga akan ke Surabaya," ujar istriku serak. Dipungutan seluler di atas meja lalu dipencetnya angka-angka. Tangannya tremor, isaknya meletup. Terdengar swuara di sebrang sana menyapa kalem sebelum disahut oleh Hanum."

(Hanum Salsabiela Rais dan Rangga Almahendra: 314) 


Kredo 4 (2021)
KREDO: Jurnal Ilmiah Bahasa dan Sastra
Terakreditasi Sinta 4 berdasarkan Keputusan
Direktorat Jenderal Penguatan Riset dan
Pengembangan, Kementerian Riset, Teknologi dan
Pendidikan Tinggi Republik Indonesia
Nomor: 23/E/KPT/2019.08 Agustus 2019
https://jurnal.umk.ac.id/index.php/kredo/index

Berdasarkan gambaran di atas tokoh utamanya dengan rela memilih berjuang untuk mendapatkan keturunan dan merelakan kariernya demi membahagiakan orang tua dan memperjuangkan rumah tangganya dan menghasilkan keturunan.

Kutipan selanjutnya yaitu. "Aku memeluk istriku, kedua tangan kami bertemu di bawah perut Hanum. Seolah aku juga merasakan tangan Sarahza juga ikut mengepal di bawah kedua tangan kami. Ketiga tangan kami berhimpun di satu titik, melebur untuk memberi semangat satu sama lain.

Sesaat lagi, pembatas berupa kulit dan otot setebal 5 milimiter akan tersingkap dengan pisau bedah. Dan kami bertiga akan dipertemukan segera, sebagai satu keluarga yang akan saling menjaga." (Hanum Salsabiela Rais dan Rangga Almahendra:352)

Kutipan di atas menjelaskan karakter tokoh utama yang sangat kuat dan pantang menyerah meskipun hidup sebagai taruhannya dalam melahirkan si buah hati yang selama ini mereka impikan. Satu keluarga saling menyemangati antara satu dengan yang lainnya.

Selanjutnya perhatikan kutipan di bawah ini.

"Bagaimanapun aku tahu istriku akan bertempur di medan syahid, bisa saja aku kehilangan istriku, atau keduanya dalam perjalanan suci ini. "Bu Hanum, kita pasang infus ya..." Suster berbicara sambil menunjukkan perantai yang selalu membuat Hanum jengah 11 tahun ini. Aku melihat ia memerintahkan Hanum mengambil napas panjang saat jarum suntik akrilik tajam dan tipis itu mencubles pembuluh darah di punggung tangan Hanum."

(Hanum Salsabiela Rais dan Rangga

Almahendra:351)

Kutipan di atas menggambarkan karakter tokoh utama yang berani disuntik dengan jarum yang selama ini dia takuti, karena hanya untuk berjuang mempertahankan anaknya sampai rasa takut yang selama ini dia miliki kini sedikit demi sedikit mulai hilang. 


Kredo 4 (2021)
KREDO: Jurnal Ilmiah Bahasa dan Sastra
Terakreditasi Sinta 4 berdasarkan Keputusan
Direktorat Jenderal Penguatan Riset dan
Pengembangan, Kementerian Riset, Teknologi dan
Pendidikan Tinggi Republik Indonesia
Nomor: 23/E/KPT/2019.08 Agustus 2019
https://jurnal.umk.ac.id/index.php/kredo/index

\section{SIMPULAN}

Berdasarkan hasil penelitian di atas maka dapat disimpulkan bahwa:

1. Tokoh utama yang berkesesuaian dengan olah hati merupakan suatu kemampuan seseorang untuk mengelola hati nurani sehingga dapat memutuskan kebenaran dan kesalahan atau perbuatan-perbuatan secara individual diri sendiri.

2. Olah pikir merupakan Kemampuan seseorang untuk mengelola akal budi untuk mempertimbangkan dan memutuskan sesuatu baik dalam memecahkan suatu permasalahan yang sedang dihadapi.

3. Tokoh utama memiliki beberapa karakter yang berkesesuaian dengan olah hati, olah pikir da nada beberapa sifat yang dimiliki oleh tokoh utama seperti, (1) sifat optimis, (2) tertarik dengan lawan jenis, (3) kuat, dan (4) pantang menyerah. Dengan sifat yang dimiliki oleh tokoh utama akhirnya usaha dan perjuangannya untuk mendapatkan keturunan tidak sia-sia dan dengan karakter yang sangat sungguh-sungguh.

\section{DAFTAR PUSTAKA}

Lauther, H. 2004. Creating chaacters: a writer's reference to the personality traits that bring fictional people to life. North Carolina: Mc Farland \& company. Inc., Publishers. Tersedia dari Google books.

Kosasih, E. 2012. Dasar-dasar Keterampilan Bersastra. Bandung: Yrama Widya.

Thomas Lickona. 2012. Chacter Matters. Jakarta: PT. Bumi Aksara.

Adisusilo, Sutarjo, Taufik. 2011. Pembelajaran Nilai-nilai Karakter Kontruktivismedan VCT sebagai Inovasi Pendekatan Pembelajaran Afektif. Jakarta: PT Grafindo Prasada.

Samani, Muchlas, Hariyanto. 2011. Konsep dan Model Pendidikan Karakter. Bandung: Remaja Rosdakarya.

Sugiyono. 2008. Metode Penelitian Kuantitatif Kualitatif dan R\&D. Bandung: ALFABETA. 